\title{
Intellectual Capital Impact on Organizations' Performance
}

\section{Sayyed Khawar Abbas ${ }^{1}$, Hafiz Ali Hassan ${ }^{1}$, Zair Mahmood Hashmi², Hafiz Muhammad Junaid ${ }^{3}$, Sikandar Majid², Tanzila Ijaz ${ }^{2}$}

\author{
${ }^{1}$ Hailey College of Commerce, University of the Punjab, Pakistan \\ ${ }^{2}$ University of Lahore, Chenab Campus, Gujrat, Pakistan \\ ${ }^{3}$ Institute of Administrative Sciences, University of the Punjab, Pakistan
}

\begin{abstract}
The abundance of traditional financial evaluation methods reflects historical performances. It is necessary to consider such elements which add value offbalance sheet towards growth. It is argued that there is the difference between book value and market value of a firm, and that difference could be explained by intellectual capital profile. The study is proposed to investigate the impact of six intellectual capital elements human capital, structural capital, customer capital, technology capital, social capital and spiritual capital on the overall performance of the firms. The impactis diagnosed. A developed questionnaire is used to conduct the study. Correlation analysis depicts the data, OLS is used to conduct the analysis.
\end{abstract}

Keywords - Intellectual capital,firms' performance, service sector, Pakistan.

\section{INTRODUCTION}

In the current century, people will tend to do more brainwork,and the tendency of physical activities will reduce. The process of economic growth will be more driven by knowledge and information rather than the production process. The knowledge and information referred to intellectual capital never appears on financial reports but have a significant impact on firms' performance as compare to physical assets (Akpinar \& Akdemir, 1999).

The globalization phenomenon has increased the interaction of individuals for their common benefits and the quest for better living standards (Hassan, Abbas, \& Zainab, 2018). Sharia screening process in a country like Pakistan having similarities and differences with other counties(Waris, Hassan, Abbas, Mohsin, \& Waqar, 2018).Financial Deficit has widened the importance of equity capital raising(Asif, Abbas, \& Hassan, 2018) .In the current scenario, intangible resources,knowledge-based economies, and various competencies have become crucial elements in the growth and progress of firms (Wang, Wang, \& Liang, 2014). According to Abbas et al. (2018), to meet the growing financial challenges in the current atmosphere, credit risk analysis along with remodeling of current practices and advancement of procedures have become pivotal for sustained progress. Intellectual Capital is one of the key determinants of financial performance of banking sector of Pakistan (Shehzadi, Abbas, \& Hassan, 2018). Economic development has seen different phases in which, Developing country like Pakistan is being engaged in the formulation of different tools to boost the economy (Hassan, Abbas, \& Shehzadi, 2008). Even investment avenues which pool the short investment and makes an idle sector of economy active are becoming part of the economy of Pakistan(Abbas S., 2017).

According to Hashim, Adeyemi, \& Alhabshi,(2018), intellectual capital refers to knowledge and expertise which adds value to the performance of the organization. The definition also referred to the knowledge management process is intellectual capital. Abbas et al. (2018), validated through their research findings that cognitive, emotional and behavioral determinants affect consumer approach. Similarly, intellectual capital indulgence significantly approaches the stakeholder's interest towards the organization.Bayburina \& Golovko(2009), explained intellectual capital consists of human capital, network capital, process capital, innovation capital and client capital. All these characteristics lead to the development of competitive advantage within the organization. The induction of innovation in the current practices surely helps to achieve competitive advantage (Abbas S. K., Hassan, Asif, Junaid, \& Zainab, 2018); (Abbas S. , Hassan, Iftikhar, $\&$ Waris, 2018)\&(Abbas S. , et al., 2018). Alike, survival and competitive earnings are highly depending on the strategic management of intellectual capital resources compared to financial ones. 
In the current economic structure, the quality human capital structure favors to become a developed nation and to maintain that status is everyone priority(Berzkalne \& Zelgalve, 2014). Furthermore, the competitiveness can be increased if the available workforce is knowledgeable, proficient and adaptable. Therefore, many nations are continuously making efforts to develop human capital and enhancing mental skills and intellectual capacity of the people(Hashim, Adeyemi, \& Alhabshi, 2018).

\section{LITERATURE REVIEW}

Wang \& Liang (2014), explained intellectual capital is a sum of knowledge competencies which help organizations to achieve growth and sustainable competitive advantage. Steward (1994), explained the intellectual capital concept was introduced to differentiate firms' book value and market value. While defining the concept of intellectual capital, there is a great deal of convergence in opinion. Meanwhile, most scholars generally agree that intellectual capital contributes towards value creation and value extraction of organizations through knowledge not only held by employees but also stored within organizations database, systems, processes and relationships (Wang, Wang, \& Liang, 2014).

Several studies have enriched the extant literature regarding interconnections between knowledge management processes and intellectual capital phenomenon (Ramadan, Dahiyat, Bontis, \& Al-Dalahmeh, 2017). The firms' ability to manage its intellectual capital is directly depending on its knowledge capability (Rajesh, Pugazhendhi, \& Ganesh, 2011). Similarly, Roos(2017) , contended the process through which a firm creates, develop and manage its knowledge resources and intellectual capital is critical for the attainment of competitive performance.

Chen \& Wang(2018) found that the role of knowledge management and intellectual capital has become crucial in the information technology sector. Likewise, Kianto(2018), argued intellectual capital resources have a significant impact on firms' financial performance. A no of similar studies explored the relationship of intellectual capital and firms' performance and concluded it has a significant impact over firms' overall performance (Bontis, Chua Chong Keow, \& Richardson, 2000; Berzkalne \& Zelgalve,
2014; Wang, Wang, \& Liang, 2014; \& Ramadan, Dahiyat, Bontis, \& Al-Dalahmeh, 2017).

Intellectual capital consists of three main elements including human capital, customer capital and structural capital(Bontis, Chua Chong Keow, \& Richardson, 2000). Additionally, Hashim, Adeyemi, \& Alhabshi(2018), further extended the research framework with the inclusion of three additional variables such as technological capital, social and spiritual capital. Human capital referred to skills, expertise and experience employees share within the organization(Baron, 2011). The customer capital is organizations' relationships with customers, suppliers, and other people and structural capital cons is ts of organizations' processes, methods, concepts, and overall system owned by the organization(Akpinar \& Akdemir, 1999).

The extended use of information technology, innovation, research and development in organization termed as technological capital whereas, social capital consists of norms and relationships resulted from organizational behavior which shapes the quality of social interactions among stakeholders contributing to the growth of the economy(Hashim, Adeyemi, \& Alhabshi, 2018). Spiritual capital emerges from ethical, spiritual and religious practices individuals adhere tothe workplace. Marques (2008), found spiritual behavior within organizational conduct leads to better corporate performance. Subsequently, the study is focusedon determining the impact of human capital, structural capital, social capital, customer capital, technological capital and spiritual capital on the overall performance of firms .

\section{RESEARCH METHODOLOGY}

Study adhere to a nature in which primary data was required,so primary data collected through developed questionnaire. The questionnairewas adopted from(Khalique, Bontis, Shaari, \& Isa, 2015)(Amrizah \& Rashidah, 2013)(Ngah \& Ibrahim, 2009). A questionnaire distributed to 950 individuals by using non-probability judgmental and convenient samplings. Only 755 responses were useable and complete. Data collected through questionnaire analyzed through reliability test. All the variables reliability around 0.70.Itdepicts that data is normal to conduct the analysis. Study model adheres following the schematic diagram. 


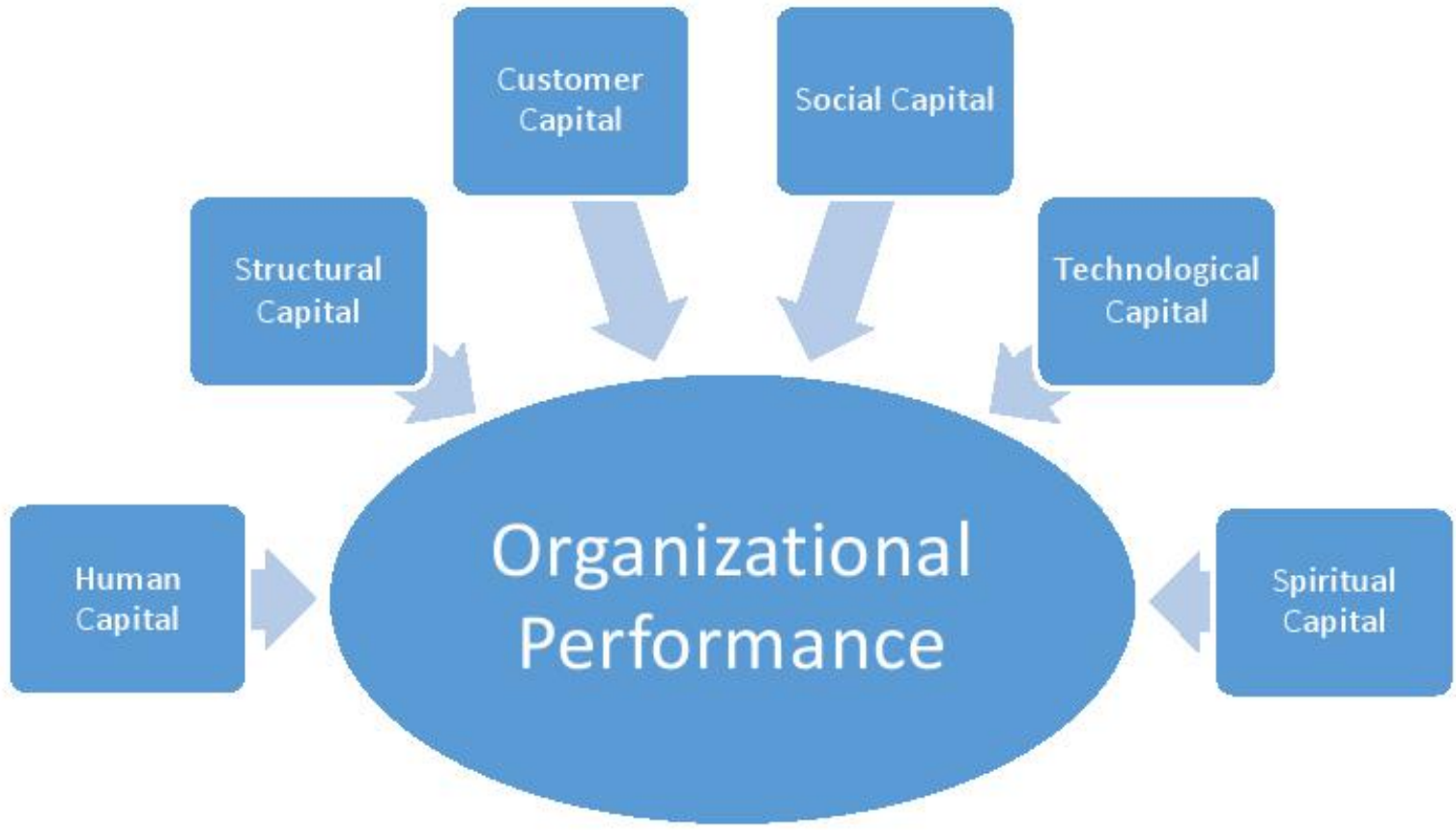

So the following hypothesis can be constructed

\begin{tabular}{llc}
\hline Hypothes is & & Details \\
\hline 1 & HC $\rightarrow$ OP \\
2 & STC $\rightarrow$ OP \\
3 & CC $\rightarrow$ OP \\
4 & SOC $\rightarrow$ OP \\
5 & TC $\rightarrow$ OP \\
6 & SPC $\rightarrow$ OP \\
\hline
\end{tabular}

HC stands for Human Capital, STC stands for Structural Capital, CC stands for Customer Capital, SOC stands for Social Capital, TC stands for Technological Capital, SPC stands for Spiritual Capital,and OP stands for Organizational performance.

\section{Research Findings}

Correlation analysis conducted to check the association between variables. The table below shows the data results of correlation analysis.

Correlation Analysis

\begin{tabular}{|c|c|c|c|c|c|c|c|}
\hline & $\mathbf{A}$ & $\mathbf{B}$ & $\mathbf{C}$ & $\overline{\mathbf{D}}$ & $\mathbf{E}$ & $\mathbf{F}$ & $\overline{\mathbf{G}}$ \\
\hline A. OP & 1 & & & & & & \\
\hline B. $\mathrm{HC}$ & $.691 * *$ & 1 & & & & & \\
\hline C. STC & $.856^{* * *}$ & $.129 * *$ & 1 & & & & \\
\hline D. $\mathrm{CC}$ & $.566^{*}$ & .014 & $.143^{* *}$ & 1 & & & \\
\hline E. SOC & $.728 * *$ & .021 & $.641 * *$ & .028 & 1 & & \\
\hline F. TC & $.860 * *$ & $.114 *$ & $.724^{*}$ & $.058 *$ & $.622 * *$ & 1 & \\
\hline G. SPC & $.518 * *$ & .033 & $.412 * *$ & .049 & $.310 * *$ & $.408 * *$ & 1 \\
\hline
\end{tabular}

Note: $* *$. Correlation is significant at the 0.01 level (2-tailed).

*. Correlation is significant at the 0.05 level (2-tailed).

It can be observed through table OP having a strong positive association with HC, STC, SOC, TC, and SPC at 1 
observe $\mathrm{HC}$, it has a strong positive as sociation with STC at

$1 \%$ level of significance and with TC at 5\% level of significance. But it does not have a significant as sociation with CC, SOC, and SPC. STC has a strong positive association with $\mathrm{CC}, \mathrm{SOC}, \mathrm{SPC}$ at $1 \%$ level of significance whereas with $\mathrm{TC}$ at $5 \%$ level of significance. $\mathrm{CC}$ has a strong positive association with $\mathrm{TC}$ at $5 \%$ of the level of significance. Whereas, it does not have a significant as sociation with SOC and SPC. SOC has strong association at $1 \%$ level of significance with $\mathrm{TC}$ and SPC. TC has a strong positive association with SPC at $1 \%$ level of significance.

\section{Reliability Analysis}

Reliability analysis shows below that internal consistency of variables are very good as it above 0.70 in all variables. So, Data could bear the analysis.

\begin{tabular}{ll}
\hline Variables & Cronbach's Alpha \\
\hline OP & 0.87 \\
HC & 0.91 \\
STC & 0.73 \\
CC & 0.76 \\
SOC & 0.79 \\
TC & 0.88 \\
SPC & 0.90 \\
\hline
\end{tabular}

\section{Multicollinearity Analysis}

Thumb rule for Multicollinearity is Tolerance less than 0.1 and VIF more than 10 show multicollinearity exist. It is to check the viability and usefulness of data, Multicollinearity analys is conducted.

\begin{tabular}{lll}
\hline Variables & \multicolumn{2}{c}{ Multicollinearity Statistics } \\
\cline { 2 - 3 } & VIF & Tolerance \\
\hline HC & 3.237 & .242 \\
STC & 4.381 & .341 \\
CC & 5.901 & .176 \\
SOC & 3.503 & .235 \\
TC & 4.536 & .281 \\
SPC & 3.473 & .311 \\
\hline
\end{tabular}

From the table results, it can be observed almost all variables fulfills the rule of thumb. Only CC contains the mild multicollinearity, but it does not require any working on it.

\section{Regression Analysis}

The model was significant, and $\mathrm{R}$ square shows that independent variables collectively explains to organizational performance $67.6 \%$. Following Table shows the results of OLS regression.

\begin{tabular}{lll} 
Variables & Coefficients & Sig. \\
\hline HC & $3.627 *$ & .051 \\
STC & $2.921 * *$ & .025 \\
CC & $3.418^{* * *}$ & .003 \\
SOC & $2.811^{* * *}$ & .006 \\
TC & $1.940 * *$ & .036 \\
SPC & $3.202 * * *$ & .009 \\
\hline
\end{tabular}

$* * * 1 \%=\mathrm{P}<.01, * * 5 \%=\mathrm{P}<.05, * 10 \%=\mathrm{P}<0.10$

It can be observed from the regression table that $\mathrm{CC}, \mathrm{SOC}$, and SPC are having a strong positive relationship at $1 \%$ level of significance. Whereas, STC and TC have a strong positive relationship at $5 \%$ level of significance. Only $\mathrm{HC}$ is having a significant positive relationship with Organizational behavior at $10 \%$ level of significance.

\section{CONCLUSION}

Intellectual Capital importance has raised with the performance evaluation for organizations in today's era. Furthermore, the low-income level has become the reason to develop the importance of intellectual capital, especially in underdeveloped nations (Abbas S. K., Hassan, Asif, \& Zainab, 2018). It also has seen that Human capital relationship with organization performance is not only the key determinants of performance. As, Quality Education in Pakistan has become a challenging part ever(Maryam, Amen, Safdar, Shehzadi, \& Abbas, 2018).So, Human Capital impacts but not much significant. Moreover, Information sharing effects broadly to employees working behavior(Hassan, Asif, Waqar, Khalid, \& Abbas, 2018) and employee engagement based on services environment of an organization (Hassan et al., 2018). It has seen that green consumption is much important now in Pakistan (Hassan $\mathrm{H}$. , Abbas, Zainab, Waqar, \& Hashmi, 2018). So study comprehend that Structural Capital, and technological capital having a significant impact at organization performance more than Human capital but still this effect not much stronger. The Strongest effect upon Organizational performance measured in the model is of customer, social and spiritual capital. Results are consistent with (Bontis, Chua Chong Keow, \& Richardson, 2000)in the nature of variables. Intellectual Capital is a very important and emerging area of research. The study isimplying top management of organizations and regularity authorities mainly. Future researchers could check the effect of intellectual capital with mediating role of motivation or dissatisfaction upon organizational performance. Even they 
could specify the population up to specific types of originations.

\section{REFERENCES}

[1] Abbas, S. (2017). Determinants of Investment Behavior of Investors towards Mutual Funds. Beau Bassin, Mauritius: Lap Lambert Academic Publishing.

[2] Abbas, S. K., Hassan, H. A., Asif, J., \& Zainab, F. (2018). HOW INCOME LEVEL DISTRIBUTION RESPONDS TO POVERTY: EMPIRICAL EVIDENCE FROM PAKISTAN. Global Scientific Journals, 6(3), 131-142.

[3] Abbas, S. K., Hassan, H. A., Asif, J., Junaid, H. M., \& Zainab, F. (2018). What are the key determinants of mobile banking Adoption in Pakistan? International Journal of Scientific \& Engineering Research, 9(2), 841-848

[4] Abbas, S. K., Hassan, H. A., Hashmi, Z. M., \& Waqar, N. (2018). HOW COGNITIVE, EMOTIONAL AND BEHAVIORAL DETERMINANTS AFFECT CONSUMER CREDIT APPROACH? Global Scientific Journals, 6(3), 164-171.

[5] Abbas, S., Haider, S., Zainab, F., Hassan, H., \& Fazal, A. (2018). Why remodeling of risk management Practices in banking is required? Evidence from Pakistan. International Journal of Scientific \& Engineering Research, 9(2), 686-691.

[6] Abbas, S., Hassan, H., Asif, J., Ahmed, B., Hassan, F., \& Haider, S. (2018). Integration of TTF, UTAUT,andITM for mobile Banking Adoption. Integration of TTF, UTAUT,andITM for mobile Banking Adoption, 4(5), 375-379.

[7] Abbas, S., Hassan, H., Iftikhar, S., \& Waris, A. (2018). Assimilation of TTF and UTAUT for Mobile Banking Usage . International Journal of Advanced Engineering, Management and Science , 4(4), 305308.

[8] Akpinar, A. T., \& Akdemir, A. (1999). Intellectual capital. In Third European Conference, (pp. (pp. 332340)).

[9] Amrizah, K., \& Rashidah, A. R. (2013). Intellectual capital profiles: Empirical evidence of Malaysian companies Kamaluddin \& Rahman. International Review of Business Research Papers, 9(6), 83-101.

[10] Asif, J., Abbas, S., \& Hassan, H. (2018). Valuation Based Test of Market Timing Theory. International Journal of Academic Multidisciplinary Research , 2(4), 28-30.
[11] Baron, A. (2011). Measuring human capital. Strategic HR Review, 10(2), 30-35.

[12] Bayburina, E., \& Golovko, T. (2009). Design of Sustainable Development: Intellectual Value of Large BRIC Companies and Factors of their Growth. Electronic Journal of Knowledge Management, 7(5), 535-558.

[13] Berzkalne, I., \& Zelgalve, E. (2014). Intellectual capital and company value. Procedia - Social and Behavioral Sciences , 110, 887-896 .

[14] Bontis, N., Chua Chong Keow, W., \& Richardson, S. (2000). Intellectual capital and business performance in Malaysian industries. . Journal of intellectual capital, 1(1), 85-100.

[15] Chen, M. H., Wang, H. Y., \& Wang, M. C. (2018). Knowledge sharing, social capital, and financial performance: the perspectives of innovation strategy in technological clusters. Knowledge Management Research \& Practice, 1-16.

[16] Hashim, M. J., Adeyemi, A. A., \& Alhabshi, S. M. (2018). Effects of Intellectual Capital on Microfinance Institutions' Performance. In Proceedings of the 2nd Advances in Business Research International Conference. (pp. 187-196). Springer, Singapore.

[17] Hassan, H. A., Abbas, S. K., \& Zainab, F. (2018). ANATOMY OF TAKAFUL. Global Scientific Journals, 6(3), 143-155.

[18] Hassan, H., Abbas, S., \& Shehzadi, A. (2008). Takafuls' Anatomy and Potential in Pakistan. Beau Bassin, Mauritius: Lap Lambert Academic Publishing.

[19] Hassan, H., Abbas, S., Zainab, F., Waqar, N., \& Hashmi, Z. (2018). Motivations for Green Consumption in an Emerging Market . Asian Journal of Multidisciplinary Studies, 6(5), 7-12.

[20] Hassan, H., Asif, J., Waqar, N., Khalid, S., \& Abbas, S. (2018). The Impact of Knowledge Sharing On Innovative Work Behavior . Asian Journal of Multidisciplinary Studies, 6(5), 22-25.

[21] Khalique, M., Bontis, N., Shaari, J. A., \& Isa, A. H. (2015). Intellectual capital in small and medium enterprises in Pakistan. Journal of Intellectual Capital, 16(1), 224-238.

[22] Kianto, A. (2018). Intellectual capital profiles and financial performance of the firm. The Routledge Companion to Intellectual Capital , 1-16.

[23] Marques, J. F. (2008). Spiritual performance from an organizational perspective: the Starbucks way. Corporate Governance, 8(3), 248-257. 
[24] Maryam, S., Amen, U.-e., Safdar, A., Shehzadi, A., \& Abbas, S. (2018). Education to Educate: A Case of Punjab Education Foundation. International Journal of Advanced Engineering, Management and Science, 4(6), 460-465.

[25] Ngah, R., \& Ibrahim, A. R. (2009). The relationship of intellectual capital, innovation and organizational performance: A preliminary study in Malaysian SMEs. International Journal of Management Innovation Systems, 1(1), 1-13.

[26] Rajesh, R., Pugazhendhi, S., \& Ganesh, K. (2011). Towards taxonomy architecture of knowledge management for third-party logistics service provider. Benchmarking: An International Journal, 18(1), 4268.

[27] Ramadan, B. M., Dahiyat, S. E., Bontis, N., \& AlDalahmeh, M. A. (2017). Intellectual capital, knowledge management and social capital within the ICT sector in Jordan. Journal of Intellectual Capital, 18(2), 437-462.

[28] Roos, G. (2017). Knowledge management, intellectual capital, structural holes, economic complexity and national prosperity. Journal of Intellectual Capital, 18(4), 745-770.

[29] Shehzadi, A., Abbas, S., \& Hassan, H. (2018). Determinants affecting the financial performance of the banking sector of Pakistan. Beau bassin, Mauritius: Lap Lambert Academic Publishing.

[30] Stewart, T. (1994). "Your company's most valuable asset: intellectual capital", . Fortune, 130(7), 68-74.

[31] Wang, Z., Wang, N., \& Liang, H. (2014). Knowledge sharing, intellectual capital and firm performance. Management decision, 52(2), 230-258.

[32] Waris, A., Hassan, H., Abbas, S., Mohsin, M., \& Waqar, N. (2018). Sharia Screening Process: A Comparison of Pakistan and Malaysia. Asian Journal of Multidisciplinary Studies, 6(5), 13-21. 